\title{
Identifying the Virulent Factors of Clostridium perfringens Locally Isolated from Different Species
}

\author{
El-Helw, H. A.*1, Taha, M. M. ${ }^{1}$, Elham F. El-Sergany', Ebtesam, E.Z. Kotb², Hussein, A. S.. ${ }^{1}$, and Abdalla, Y. A. ${ }^{1}$ \\ ${ }^{1}$ Veterinary Serum and Vaccine Research Institute, Agriculture Research Center, Abbasia, Cairo, Postcode: 11381, Egypt. \\ ${ }^{2}$ Animal Reproduction Research Institute, Agriculture Research Center, El-Haram, Giza, Postcode:12619, Egypt. \\ *Corresponding author's Email: hamedelhelw@hotmail.com; (iD)RCiD: 0000-0003-2851-9632
}

\begin{abstract}
Clostridium perfringens incriminated in many diseases among different species of animals due to its ability to produce many virulence factors. In the current study, 135 intestinal samples were collected from different animal species of different localities in Egypt. Samples were subjected to isolation and identification (morphologically and biochemically) for obtaining Clostridium perfringens isolates $(n=26,19.25 \%)$. The PCR was carried out to elucidate the virulence factors. It was indicated that all the 26 Clostridium perfringens isolates had CPA gene and Clostridium perfringens enterotoxin (CPE gene), whereas $23 \%$ of isolates of chicken and cattle intestinal samples contained $\mathrm{CPA}$, Net B, and CPE genes as virulence factors. Consequently, those isolates are highly recommended to be used in the preparation of enterotoxemia and necrotic enteritis vaccines as they are more virulent strains.
\end{abstract}

Keywords: Clostridium perfringens, CPA gene, CPE gene, Net B gene

\section{INTRODUCTION}

Clostridium perfringens (C. perfringens) is considered to be one of the most pathogen that is widely distributed in nature (Uzal et al., 2014), two key features that cause wide pathogenicity are the potential of production many virulence factors and the ability to form resistant spores. Virulent $C$. perfringens isolates produce 16 protein toxins that are important for the development of different diseases, such as food poisoning, antibiotic associated diarrhea, fatal gas gangrene, enterotoxaemia, and hemorrhagic gastroenteritis (Jihong et al., 2016). C. perfringens is a Gram-positive, spore forming anaerobic bacterium that causes serious infections in humans and animals by producing different toxins (Mariele et al., 2020). C. perfringens isclassified into five toxin types (A, B, C, D, and E) according to the production of four major toxins namely alpha (CPA), beta (CPB), epsilon (ETX) and iota (ITX) (Ferreiraet al., 2016). C. perfringens type A strains are defined by producing alpha toxin, while type B produces alpha, beta and epsilon toxins, Alpha and beta toxins produced by type $\mathrm{C}$ while type $\mathrm{D}$ produces alpha and epsilon toxins, whereas type $\mathrm{E}$ produces alpha and iota toxins (Garmory et al., 2000).

The alpha toxin of $C$. perfringens (CPA) is a $43 \mathrm{k}$ Da protein consists of 370 amino acids. It has been formed by two domains, an alpha-helical N-terminal domain harbouring the phospholipase $\mathrm{C}$ active site, and C-terminal domain which is involved in membrane binding $\alpha$-toxin and has lethal, haemolytic, phosphatidylcholine Phospholipase C(PLC) and sphingomyelinase activities (Yang et al., 2018). The four major lethal toxins are not the only biomedically important toxins as some of the $C$. perfringens isolates produce $C$. perfringens enterotoxin (CPE), and necrotic enteritis B-like toxin (Net B) (Gibert et al., 1997). Enterotoxin (CPE) is a $35 \mathrm{k}$ Da polypeptide and it consists of three domains. Domain I which is C-terminal, responsible for binding of receptors while domain II is responsible for oligomerization and membrane insertion, and domain III takes part in physical changes in course of insertion into membranes (Kitadokoro et al., 2011). Net B has been associated with enteric diseases in a wide range of animals (Boujon et al., 2005). It is an accessory toxin in $C$. perfringens mediated antibiotic associated diarrhoea (Fisher et al., 2005). Net B gene distinguishes virulent strains of $C$. perfringens that are capable of inducing necrotic enteritis in poultry from strains that do not cause this syndrome (Keyburn et al., 2006).

This study was aimed to evaluate the virulence factors among $C$. perfringens and consequently use the most virulent isolates in preparing the vaccines to control necrotic enteritis and enterotoxaemia among animals.

\section{MATERIALS AND METHODS}

\section{Ethical approval}

All procedures were performed according to Egyptian ethical standards of the National Research Committee. 


\section{Sample collection}

A total number of 135 intestinal samples were collected from different animal species (20 cattle samples, 20 sheep samples,40 rabbit samples, 30 chicken samples, 20 turkey samples, and 5 ostrich samples) during September and October of 2019 in Anaerobic Research Department, Veterinary Serum and Vaccine Research Inst., Cairo, Egypt. These samples were collected from different localities in El-Giza, El-Fayoum and Beni-Suef governorates in Egypt. Samples were collected just recently after death of sick animals and the parts of intestine (duodenum, ileum, caecum, and proximal colon) were tied from two sides and transfer to laboratory for isolation. These animals before death were suffer from sudden onset of diarrhoea with offensive odour specially in cattle and sheep samples, rabbit suffer from sever distension and diarrhoea prior to death and post mortem examination revealed that there was severe inflammation and haemorrhage in walls of small intestine and caecum.

\section{Bacteriological isolation}

Samples were diluted in PBS (1/10), incubated at $80^{\circ} \mathrm{C}$ for 10 minutes (Ahsani et al., 2010) and subsequently a loopful from each sample was cultivated on $5 \%$ sheep blood agar and anaerobically incubated using Gas pack system (Oxoid Ltd., England) at $37^{\circ} \mathrm{C}$ for 24 hours. Selected colonies were inoculated into cooked meat medium and incubated anaerobically at $37^{\circ} \mathrm{C}$ for 24 hours (Willis, 1977).

\section{Identification of the isolates}

Microscopic examination

Prepared smears from suspected colonies were stained by Gram staining and examined under oil immersion microscope (magnified 100x) according to Wilson and Miles (1975).

\section{Colonial morphology}

The Size and morphology (visual appearance of bacterial colonies on blood agar) as well as the haemolytic activity (zone of haemolysis) of the suspected colonies were examined according to Vaikosen and Muller (2001).

\section{Biochemical and sugar fermentation tests}

The catalase (by adding hydrogen peroxide and examine the formation of gas bubbles), oxidase (oxidase reagent was added and the positive results indicated if color changed), Indole (by using indole reagent and examine the change of color) and sugar fermentation tests were performed on suspected cultures according to Eyre (2009). Gelatin liquefaction test was done to detect the ability of the organism to produce gelatinase which hydrolysis the gelatin, according to Macfaddin (2000).

\section{Nagler test}

The Nagler test was done on Egg yolk agar plates according to Forbes et al. (2007) for the identification of lecithinase activity of alpha toxin of $C$. perfringens.

\section{Dermonecrotic reaction}

One side of shaved back of albino Guinea pig was injected by the prepared toxin while the other side injected by toxin after neutralization with standard antitoxin. The lesion of the reaction was interpretive according to Sterne and Batty (1975).

\section{Toxicity test of the isolates}

Toxin production medium were inoculated by pure colonies of isolates according to Chou (1971) and incubated at $37^{\circ} \mathrm{Cand} \mathrm{pH} 7.4$ for 4 hours. Sample was collected and centrifuged at $6000 \mathrm{rpm} / 20 \mathrm{~min}$. The supernatant was taken and assayed for determination of lethality of the toxin as described by Fu et al. (2004).

\section{DNA extraction}

DNA extraction from samples was performed using the QIA amp DNA Mini kit (Qiagen, Germany, GmbH) with modifications based on the recommendations of manufacturer. Briefly, $200 \mu \mathrm{l}$ sample from suspension was incubated with $10 \mu \mathrm{l}$ of proteinase $\mathrm{K}$ and $200 \mu \mathrm{l}$ of lysis buffer at $56^{\circ} \mathrm{C}$ for $10 \mathrm{~min}$. After incubation, $200 \mu \mathrm{l}$ of $100 \%$ ethanol was added to the lysate. The sample was then washed and centrifuged following the manufacturer's recommendations. Nucleic acid was eluted with $100 \mu \mathrm{l}$ of elution buffer provided in the kit.

\section{PCR amplification}

Oligonucleotide primers that used in current study were supplied from Metabion (Germany) and they have been listed in Table 1. The multiplex PCR for toxins was performed according to Meer and Songer (1997). The primers were utilized in a 50- $\mu 1$ reaction containing $25 \mu 1$ of Emerald Amp® Max PCR Master Mix (Takara, Japan), $1 \mu 1$ of each primer of 20 pmol concentration, $11 \mu \mathrm{l}$ of water, and $6 \mu 1$ of DNA template. The reaction was performed in an Applied bio system 2720 Thermal Cycler. The Uniplex PCR for Net B or CPE was performed. The primers were used in a $25-\mu 1$ 
reaction containing $12.5 \mu \mathrm{l}$ of Emerald Amp® Max PCR Master Mix (Takara, Japan), $1 \mu$ l of each primer of 20 pmol concentration, $5.5 \mu \mathrm{l}$ of water, and $5 \mu \mathrm{l}$ of DNA template. The reaction was performed in an Applied bio system 2720 Thermal Cycler.

\section{Analysis of the PCR products}

Electrophoresis (1.5\% agarose gel, AppliChem, Germany, $\mathrm{GmbH}$ ) was performed to separate the products of in $1 \times$ TBE buffer at room temperature by using gradients of $5 \mathrm{~V} / \mathrm{cm}$. In each gel slot, $30 \mu \mathrm{l}$ of the products was loaded. The fragment sizes were determined by using Gelpilot100 bp DNA Ladder (Qiagen, Germany, GmbH). The gel was photographed by a gel documentation system (Alpha Innotech, Bio metra) and the data was analysed through computer software (Automatic Image Capture, USA).

Table 1. Primers sequences, target genes, amplicon sizes and cycling conditions that were used for PCR amplification of DNA extracts of Clostridium perfringens isolates

\begin{tabular}{|c|c|c|c|c|c|c|c|c|}
\hline \multirow[b]{2}{*}{$\begin{array}{l}\text { Target } \\
\text { gene }\end{array}$} & \multirow[b]{2}{*}{ Primers sequences } & \multirow{2}{*}{ 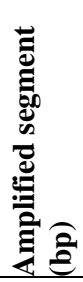 } & \multirow[b]{2}{*}{ 苞晜 } & \multicolumn{3}{|c|}{ Amplification (35 cycles) } & \multirow{2}{*}{ } & \multirow[b]{2}{*}{ 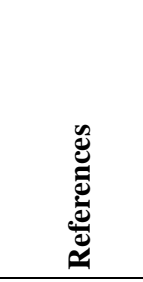 } \\
\hline & & & & 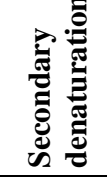 & 涕 & 馬 & & \\
\hline \multirow{2}{*}{ Alpha } & GTTGATAGCGCAGGACATGTTAAG & \multirow{2}{*}{402} & \multirow{8}{*}{$\begin{array}{l}94^{\circ} \mathrm{C} \\
5 \mathrm{~min} .\end{array}$} & \multirow{8}{*}{$\begin{array}{c}94^{\circ} \mathrm{C} \\
45 \mathrm{sec} .\end{array}$} & \multirow{8}{*}{$\begin{array}{c}50^{\circ} \mathrm{C} \\
45 \mathrm{sec} .\end{array}$} & \multirow{8}{*}{$\begin{array}{c}72^{\circ} \mathrm{C} \\
45 \mathrm{sec} .\end{array}$} & \multirow{8}{*}{$\begin{array}{c}72^{\circ} \mathrm{C} \\
10 \mathrm{~min} .\end{array}$} & \multirow{8}{*}{$\begin{array}{l}\text { YOO et al. } \\
\quad(1997)\end{array}$} \\
\hline & CATGTAGTCATCTGTTCCAGCATC & & & & & & & \\
\hline Beta & ACTATACAGACAGATCATTCAACC & 236 & & & & & & \\
\hline & TTAGGAGCAGTTAGAACTACAGAC & & & & & & & \\
\hline \multirow{2}{*}{ Epsilon } & ACTGCAACTACTACTCATACTGTG & \multirow{2}{*}{541} & & & & & & \\
\hline & CTGGTGCCTTAATAGAAAGACTCC & & & & & & & \\
\hline \multirow{2}{*}{ Iota } & GCGATGAAAAGCCTACACCACTAC & \multirow{2}{*}{317} & & & & & & \\
\hline & GGTATATCCTCCACGCATATAGTC & & & & & & & \\
\hline \multirow{2}{*}{ Net B } & GCTGGTGCTGGAATAAATGC & \multirow{2}{*}{560} & \multirow{2}{*}{$\begin{array}{c}94^{\circ} \mathrm{C} \\
5 \mathrm{~min} .\end{array}$} & \multirow{2}{*}{$\begin{array}{c}94^{\circ} \mathrm{C} \\
30 \mathrm{sec} .\end{array}$} & \multirow{2}{*}{$\begin{array}{c}58^{\circ} \mathrm{C} \\
40 \mathrm{sec} .\end{array}$} & \multirow{2}{*}{$\begin{array}{c}72^{\circ} \mathrm{C} \\
45 \mathrm{sec} .\end{array}$} & \multirow{2}{*}{$\begin{array}{c}72^{\circ} \mathrm{C} \\
10 \mathrm{~min} .\end{array}$} & \multirow{2}{*}{$\begin{array}{c}\text { Datta et al. } \\
\quad(2014)\end{array}$} \\
\hline & TCGCCATTGAGTAGTTTCCC & & & & & & & \\
\hline \multirow{2}{*}{$\begin{array}{l}\text { Enterotoxin } \\
\text { (CPE gene) }\end{array}$} & ACATCTGCAGATAGCTTAGGAAAT & \multirow{2}{*}{247} & \multirow{2}{*}{$\begin{array}{c}94^{\circ} \mathrm{C} \\
5 \mathrm{~min} .\end{array}$} & \multirow{2}{*}{$\begin{array}{c}94^{\circ} \mathrm{C} \\
30 \mathrm{sec} .\end{array}$} & \multirow{2}{*}{$\begin{array}{c}55^{\circ} \mathrm{C} \\
30 \mathrm{sec} .\end{array}$} & \multirow{2}{*}{$\begin{array}{c}72^{\circ} \mathrm{C} \\
30 \mathrm{sec} .\end{array}$} & \multirow{2}{*}{$\begin{array}{c}72^{\circ} \mathrm{C} \\
10 \mathrm{~min} .\end{array}$} & \multirow{2}{*}{$\begin{array}{l}\text { Kaneko et } \\
\text { al. (2011) }\end{array}$} \\
\hline & CCAGTAGCTGTAATTGTTAAGTGT & & & & & & & \\
\hline
\end{tabular}

\section{RESULTS}

\section{Bacterial identification of isolates}

\section{Morphological characterization}

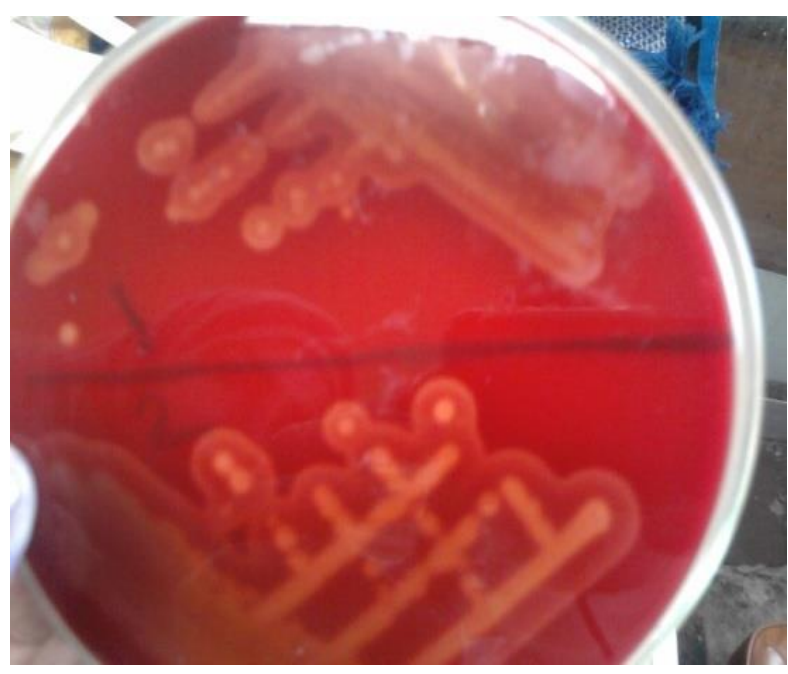

Figure 1. Colonies streaked on blood agar plate have shown a double zone of hemolysis (inner zone shown complete zone of hemolysis, and outer zone for incomplete hemolysis)

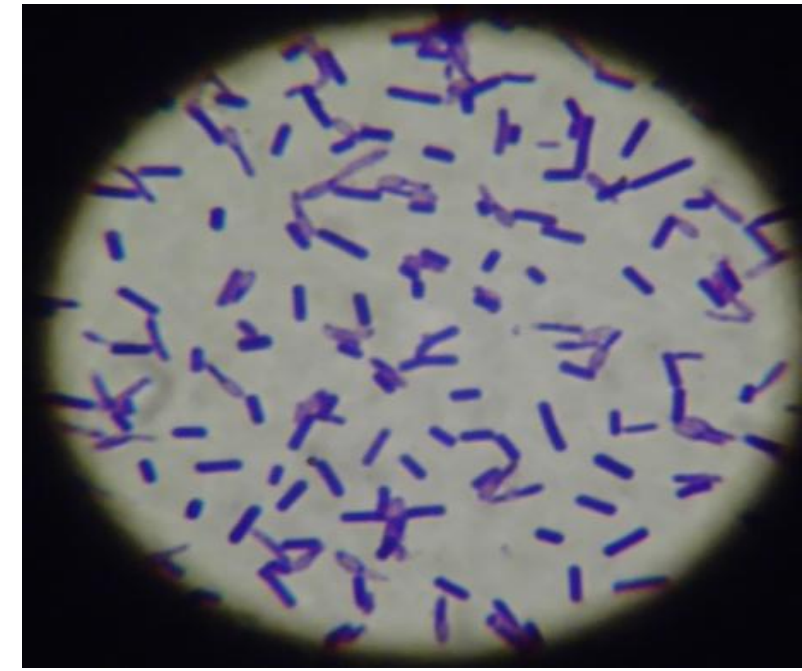

Figure 2. Gram staining of smear from suspected colonies that have shown Gram-positive bacilli 


\section{Biochemical characteristics}

The number of 26 C. perfringens isolates were collected from 135 intestinal samples as presented in Table2.Those colonies that presented double zone of hemolysis when inoculated in blood agar and revealed as Gram-positive bacilli were further examined for their biochemical reactions and toxicity test, as they were catalase, oxidase, and Indole tests negative and liquefies gelatin. Sugar fermentation (glucose, sucrose, maltose and lactose) of isolates was positive and also their Nagler's reaction was positive. Figure 3 indicated clear opalescence zone in the antitoxin free side (right) while it was inhibited in the left side where the antitoxin was added (no clear opalescence) due to toxin-antitoxin neutralization.

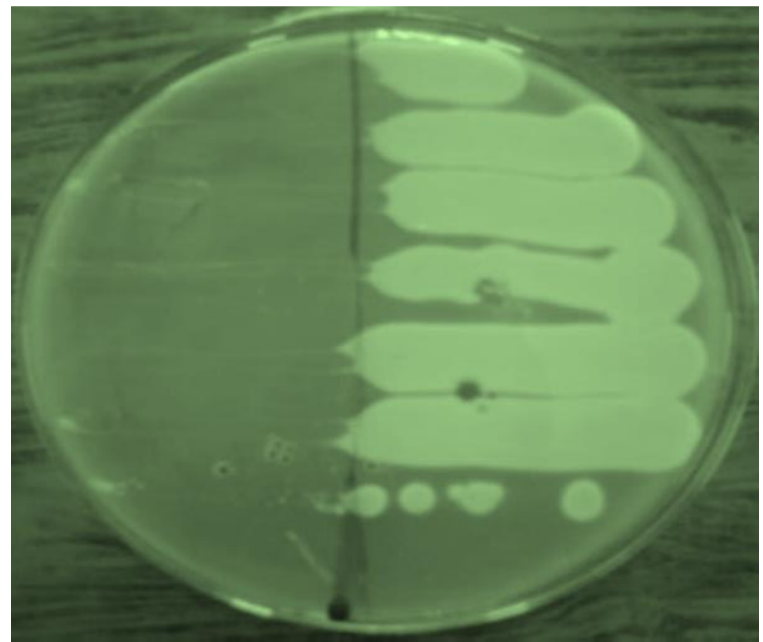

Figure 3. Nagler`s reaction on egg yolk agar for the isolates

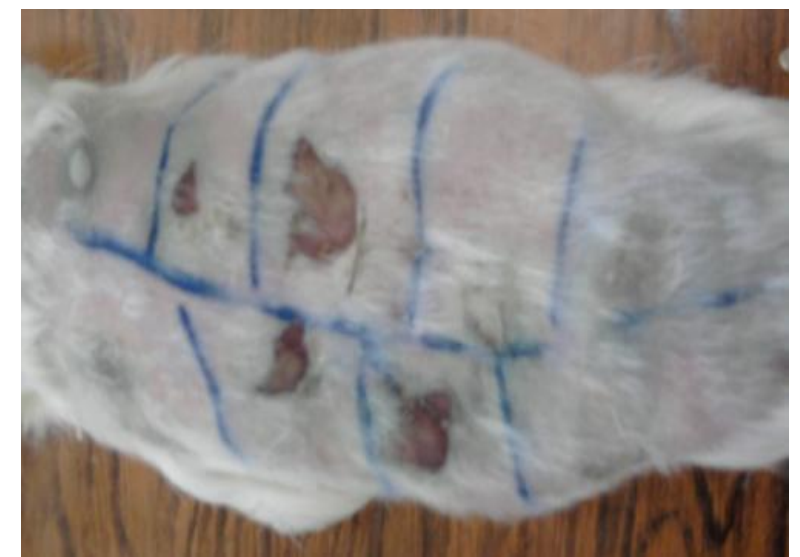

Figure 4. Dermonecrotic reaction performed on Guinea pig, the right side was inoculated by toxin and antitoxin, while the left side has indicated lesion on skin due to incubation only by toxin.

\section{Toxicity test}

All 26 isolates that have been inoculated in three mice for each isolate caused that inoculated mice died within 24 hours.

Table 2. Genotyping of Clostridium perfringens isolates from different animal species

\begin{tabular}{l|c|c|c|c|c|c|c|c}
\hline \multirow{2}{*}{$\begin{array}{l}\text { Animal } \\
\text { specie }\end{array}$} & $\begin{array}{c}\text { No. of } \\
\text { samples } \\
\text { collected }\end{array}$ & $\begin{array}{c}\text { C. perfringens } \\
\text { positive } \%\end{array}$ & CPA & CPB & ETX & CPIi & Net B & CPE \\
\hline Cattle & 20 & $(4 / 20) 20$ & $(4 / 4) 100$ & 0 & 0 & 0 & $(4 / 4) 100$ & $(4 / 4) 100$ \\
\hline Sheep & 20 & $(6 / 20) 30$ & $(6 / 6) 100$ & 0 & 0 & 0 & 0 & $(6 / 6) 100$ \\
\hline Rabbit & 40 & $(10 / 40) 25$ & $(10 / 10) 100$ & 0 & 0 & 0 & 0 & $(10 / 10) 100$ \\
\hline Chicken & 30 & $(2 / 30) 6.66$ & $(2 / 2) 100$ & 0 & 0 & 0 & $(2 / 2) 100$ & $(2 / 2) 100$ \\
\hline Turkey & 20 & $(3 / 20) 15$ & $(3 / 3) 100$ & 0 & 0 & 0 & 0 & $(3 / 3) 100$ \\
\hline Ostrich & 5 & $(1 / 5) 20$ & $(1 / 1) 100$ & 0 & 0 & 0 & 0 & $(1 / 1) 100$ \\
\hline
\end{tabular}

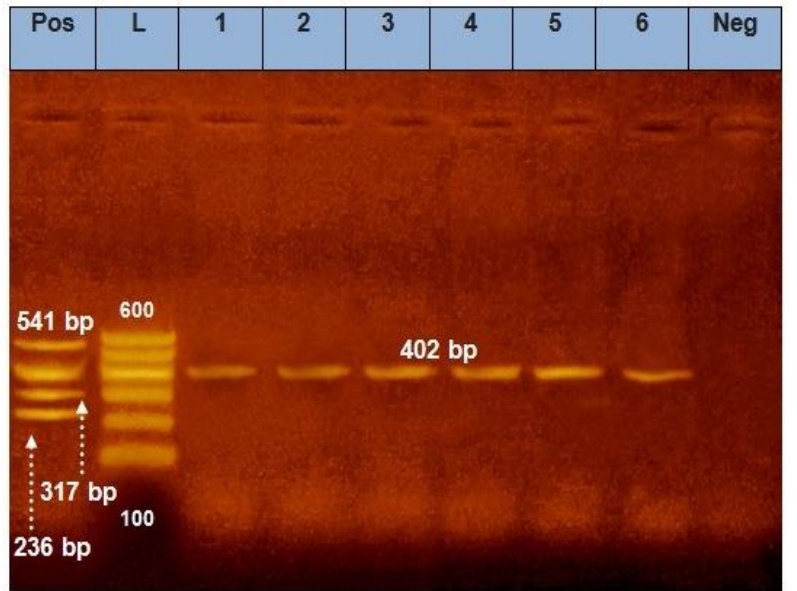

Figure 5. Agarose gel for Multiplex PCR of toxins. Lane (L): 100bp DNA Ladder, Lane Positive: Clostridium perfringens strains type $\mathrm{B}$ and $\mathrm{E}$ served as a positive control, Lane Negative: Negative, Lanes (1-6): samples isolated 1: Turkey, 2: Chicken, 3: Ostrich, 4: Rabbit, 5: Sheep, and 6: Cattle.

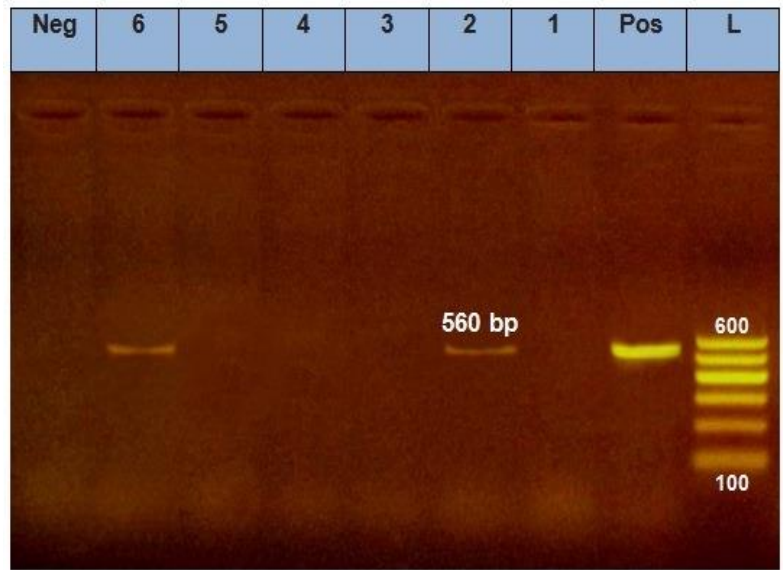

Figure 6. Agarose gel for Uniplex of Net B. Lane (L): 100bp DNA Ladder, Lane Positive: Positive control for Net B gene, Lane Negative: Negative, Lanes (1-6): Samples isolated. 1: Turkey, 2: Chicken, 3: Ostrich, 4: Rabbit, 5: Sheep, and 6: Cattle. 


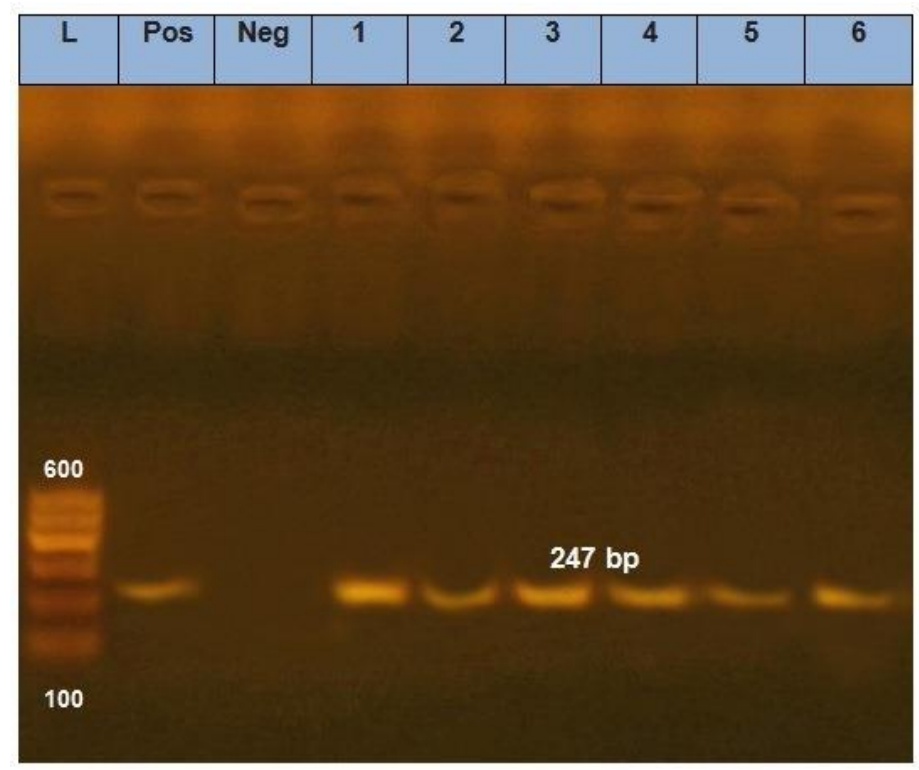

Figure 7. Agarose gel for uniplex of CPE. Lane (L): 100bp DNA Ladder, Lane Positive: Positive control for CPE gene, Lane Negative: Negative, Lanes (1-6): Samples isolated. 1: Turkey, 2: Chicken, 3: Ostrich, 4: Rabbit, 5: Sheep, and 6: Cattle.

\section{Genotyping of the isolates}

The 26 number of $C$. perfringens collected isolates (19.25\%) from 135 intestinal samples were all CPA and CPE genes positive by multiplex PCR which included the number of 4 isolates (20\%) from total 20 cattle samples, 6 isolates (30\%) from total 20 sheep samples, 10 isolates (25\%) from total 40 rabbit samples, 2 isolates (6.66\%) from total 30 chicken samples, 3 isolates (15\%) from total 20 turkey samples and 1 isolate (20\%) from total 5 ostrich samples. The Net $\mathrm{B}$ gene was positive in six isolates (two isolates from chicken and four isolates from cattle).

\section{DISCUSSION}

$C$. perfringens can produce four major toxins $(\alpha, \beta, \varepsilon$, and $\imath)$ and is accordingly divided into five serotypes, from A to $\mathrm{E}$ (Zhang et al., 2020). All five serotypes of $C$. perfringens carry and express the alpha toxin structural gene, but most of type A strains produce alpha toxin, while beta toxin is a major lethal toxin produced by both types B and $\mathrm{C}$ strains of $C$. perfringens. Epsilon toxin is produced as a proto toxin and activated by the proteolytic enzymes that produced by the same organism (Popoff, 2014). Mainly iota toxin secreted by type E of C. perfringens and consists of two separate proteins that are immunologically and chemically distinct (Awad et al., 2001).

Several virulence factors of $C$. perfringens including enterotoxins and Net B toxin have been studied (Silva et al., 2013). C. perfringens enterotoxin (CPE) is a $35 \mathrm{kDa}$ polypeptide consisting of three domains. The CPE forms an active pore that enhances calcium influx, consequently leads to cell death and intestinal damage (Freedman et al., 2016). Results from current study revealed that all isolates characterized by presence of CPE gene, and it comes in accordance with Li et al. (2010) who mentioned that the most CPE gene positive strains of C. Perfringens was classified as type A, moreover, type $\mathrm{C}$ and $\mathrm{D}$ strains are fairly common to produce the enterotoxin

In this study, 135 intestinal samples from different animal and poultry species were taken and the causative organism was isolated on cooked meat medium then streaked on blood agar as illustrated in figure 1double zone of hemolysis of the colonies (inner shown complete zone of hemolysis, and outer incomplete zone of hemolysis) have been detected in 26 samples from 135 intestinal samples, then the colonies of each blood agar plate were smeared and Gram stained separately, where Gram-positive bacilli seen in 26 out of 135 of the smears (Figure 2).

Biochemical tests for the isolates revealed that they were oxidase, catalase and indole tests negative, the isolates positively ferment glucose, sucrose, maltose and lactose. Figure 3 indicated that the isolates showed clear opalescence zone in the antitoxin free side, while in the side where the antitoxin was added, it was inhibited due to toxin-antitoxin neutralization. These results primarily concluded that 26 isolates from the 135 collected samples were $C$. perfringens as mentioned by Willis (1977).

Genotyping of the isolates was done by multiplex PCR using primers sequences, for the four major toxins genes as indicated in table1. The PCR results revealed that alpha toxin gene (402bp) was only detected among the major toxin in the obtained isolates (Figure 5). These results came in contact with the fact that alpha toxin is the virulence factor which is produced by all types of $C$. perfringens (Titball et al., 2000). 
Uniplex PCR for Net B and CPE genes by using their specific primer sequences 546 and 247 bp respectively, was performed separately as it has been presented in table 1. Figure 6 based on the Agarose gel of uniplex PCR using Net B primer revealed that six isolates(two from chicken and four from cattle)which previously had been isolated, were the only ones that contained Net B gene as a virulence factor beside the major alpha toxin, these results were in complete agreement with Anthony et al. (2006) as they stated alpha toxin is not the only essential causative agent of necrotic enteritis in chickens and this provides the basis for further studies to identify virulence factors. Moreover, Anthony et al. (2010) identified Net B in C. perfringens type A strains isolates from chickens suffering necrotic enteritis. Also, Thomas and Joan (2009) detected Net B gene in isolates of American strains of $C$. perfringens from chickens and cattle.

The results in Table 2 indicated that the $C$. perfringens type A isolates had Net B gene obtained from infected chickens which recently died and had sever inflammation in caecum and enteritis. This finding proved by Keyburn et al. (2010) who found that the majority of strains isolated from necrotic enteritis affected birds were Net B gene positive and there was correlation between Net B and in vitro expression of Net B protein and provide the evidence that Net B is important in pathogenesis as virulence factor for $C$. perfringens.

On the other side, the results from the Uniplex PCR by using CPE primer which has been illustrated inFigure7, revealed that $C$. perfringens enterotoxin secreted by all of the 26 isolates. Freedman et al. (2016) previously concluded that most CPE positive strains classify as $C$. perfringens type $\mathrm{A}$ and also added that during the disease when $C$. perfringens sporulates in the intestines, CPE produces, a process that in volves several sporulation specific alternative sigma factors.

\section{CONCLUSION}

Based on results from current study, it could be concluded that among 26 Clostridium perfringens isolates from different species, six isolates that have been isolated from chicken and cattle (two and four respectively) contained CPA, Net B and CPE genes as virulence factors and hence can be used in preparation of enterotoxaemia and necrotic enteritis vaccines from Clostridium perfringens type A as they are the more virulent strains. The authors of present study also recommend further studies on the virulence factors of Clostridium perfringens.

\section{DECLARATIONS}

\section{Authors' contribution}

El-Helw H.A. and Taha M.M. isolated Clostridium perfringens from the samples, El-Sergany E.F. identified the isolates by using morphological and biochemical tests. Ebtesam E.Z. Kotb and Hussein A.S. provided samples from farms while El-Helw H.A. and Abdalla Y.A. performed genotyping of isolates.

\section{REFERENCES}

Ahsani MR, Mohammadabadi MR, and Shamsaddini MB (2010). Clostridium perfringens isolates typing by multiplex PCR. Journal of Venomous Animals and Toxins including Tropical Diseases, 16: 573-578. DOI: https://www.doi.org/10.1590/S1678$\underline{91992010000400006}$

Anthony K, Sheedy S, Mark F, Williamson M, Milena A, Rood J, and Moore R (2006). Alpha toxin of Clostridium perfringens is not an essential virulence factor in necrotic enteritis in chickens. Infection and Immunity, 74(11): 6469-6500. DOI: https://www.doi.org/10.1128/IAI.00806-06

Anthony LK, Trudi LB, Robert JM, and Julian I (2010). Net B, a Pore-Forming Toxin from Necrotic Enteritis Strains of Clostridium perfringens. Toxins, 2: 1913-1927. DOI: https://www.doi.org/10.3390\%2Ftoxins2071913

Awad MM, Ellemor DM, Boyd RI, Emmins JJ, and Rood JI (2001). Synergestic effects of alpha toxin and perfringolysin O in Clostridium perfringens mediated gas gangrene. Infection and Immunity Journal, 69: 7904-7910. DOI: https://www.doi.org/10.1128/IAI.69.12.7904-7910.2001

Boujon P, Henzi M, Penseyres JH, and Belloy L (2005). Enter otoxemia involving beta2-toxigenic Clostridium perfringens in a white stork (Ciconiaciconia). The Veterinary Research, 156: 746-747. DOI: https://www.doi.org/10.1136/vr.156.23.746

Chou G (1971). Medium for toxin production by Clostridium perfringens in continuous culture. Applied Microbiology, 21(5): 794798. PMCID: 377283

Datta S, Rakha NK, Narang G, Arora D, and Mahajan NK (2014). Prevalence of $\alpha$, $\beta$, and Net B toxin producing strains of Clostridium perfringens in broiler chickens in Harayana. Haryana Veterinarian, 53(1): 39-42. Available at: https://www.luvas.edu.in/haryana-veterinarian/download/harvet2014/9.pdf

Eyre JWH (2009). The Project Gutenberg eBook of The Elements of Bacteriological Technique, A Laboratory Guide for Medical, Dental, and Technical Students. Second Edition Rewritten and Enlarged. eBook \#27713 ISO-8859-8861. Available at: http://www.gutenberg.org/files/27713/27713-h/27713-h.htm

Ferreira MR, Gustavo MS, Carlos E, Marcelo M, Felipe M, Ângela N, and Fabricio RC (2016). Recombinant Alpha, Beta, and Epsilon Toxins of Clostridium perfringens: Production Strategies and Applications as Veterinary Vaccines Toxins, 8: 340-362. DOI: http://www.doi.org/10.3390/toxins8110340 
Fisher DJ, Miyamoto K, Harrison B, Akimoto S, Sarker Mr, and McClane BA (2005). Association of beta2 toxin production with Clostridium perfringens type A human gastrointestinal disease isolates carrying a plasmid enterotoxin gene. Molecular Microbiology, 56: 747-762. DOI: https://www.doi.org/10.1111/j.1365-2958.2005.04573.x

Forbes B, Daniel S, and Alice W (2007). Bailey and Scott's Diagnostic Microbiology, C.V. Mosby Company, St. Louis, MO. 12th ed. Pp. 182-191. Available at: https://www.worldcat.org/title/bailey-scotts-diagnostic-microbiology/oclc/77256475

Freedman JC, Shrestha A, and McClane BA (2016). Clostridium perfringens Enterotoxin: Action, Genetics, and Translational Applications. Toxins, (8): 73-81. DOI: https://www.doi.org/10.3390/toxins8030073

Fu SW, Xue J, Zhang YL, and Zhou DY (2004). Simplified purification method for Clostridium difficile toxin A. World Journal of Gastroenterology, 10(18): 2756- 2758. DOI: https://www.doi.org/10.3748/wig.v10.i18.2756

Garmory HS, Chanter N, and French NP (2000). Occurrence of Clostridium perfringens beta2-toxin amongst animals, determined using genotyping and subtyping PCR assays. Epidemiology Infection, 124: 61-67. DOI: https://www.doi.org/10.1017/s0950268899003295

Gibert M, Jolivet-Reynaud C, and Popoff MR (1997). Beta2 toxin, a novel toxin produced by Clostridium perfringens. Gene, 203: 6573. DOI: https://www.doi.org/10.1016/s0378-1119(97)00493-9

Jihong L, Daniel P, Mahfuzur RS, and Clane BAM (2016). Clostridium perfringens Sporulation and Sporulation-Associated Toxin Production. Microbiology Spectrum Journal, 4(3): 1-26. DOI: http://www.doi.org/10.1128/microbiolspec.TBS-0022-2015

Kaneko I, Miyamoto K, Mimura K, Yumine N, Utsunomiya H, Akimoto S, and McClane BA (2011). Detection of Enter otoxigenic Clostridium perfringens in Meat Samples by Using Molecular Methods. Applied and Envir. Microbiol, pp. 7526-7532. DOI: https://www.doi.org/10.1128\%2FAEM.06216-11

Keyburn AL, Scott AS, Mark EF,Mark MW,Milena MA, Julian IR, and Robert JM (2006). Alpha-Toxin of Clostridium perfringens Is Not an Essential Virulence Factor in Necrotic Enteritis in Chickens. Infection and Immunity, 74(11): 6496-6500. DOI: https://www.doi.org/10.1128/IAI.00806-06

Keyburn AL, Yan X,Bannam TL, Van Immerseel FV, Rood JI, and Moore RJ (2010). Association between avian necrotic enteritis and Clostridium perfringens expression Net B toxin. Veterinary Research, 14: 21. DOI: https://www.doi.org/10.1051/vetres/2009069

Kitadokoro K, Nishimura K, Kamitani S, Fukui-Miyazaki A, Toshima H, Abe H, Kamata Y, Sugita-Konishi Y, Yamamoto S, and Karatani H (2011). Crystal structure of Clostridium perfringens enterotoxin displays features of beta-pore-forming toxins. Journal of Biological Chemistry, 286: 19549-19555. DOI: https://www.doi.org/10.1074/jbc.M111.228478

Li J, Miyamoto K, Sayeed S, and McClane BA (2010). Organization of the cpe locus in CPE-positive Clostridum perfringens type C and D isolates. PLoS One, 5: e10932. DOI: https://www.doi.org/10.1371/journal.pone.0010932

MacFaddin JF (2000). Biochemical tests for identification of medical bacteria, 3rd Edition. Baltimore (Md.): Williams and Wilkins, p.928. Available https://www.scirp.org/(S(lz5mqp453edsnp55rrgjct55))/reference/ReferencesPapers.aspx?ReferenceID=1661468

Mariele S, Rubén P, Schocken I, Lívia B, Andressa P, and Karin W (2020). Necrotic Enteritis Caused by Clostridium perfringens in Blue and Gold Macaws (Araararauna). Journal of Avian Medicine and Surgery, 34(1): 65-69. DOI: https://www.doi.org/10.1647/1082-6742-34.1.65

Meer RR, and Songer JG (1997). Multiplex polymerase chain reaction assay for genotyping Clostridium perfringens. American Journal of Veterinary Research, 58(7): 702-705. Available at: https://pubmed.ncbi.nlm.nih.gov/9215442/

Popoff MR (2014). Clostridial pore-forming toxins: powerful virulence factors. Anaerobe, 30: $220-238$. DOI: https://www.doi.org/10.1016/j.anaerobe.2014.05.014

Silva R, Ribeiro M, Palhares S, Borges AS, Maranhão RPA, and Silva MX (2013). Detection of A/B toxin and isolation of Clostridium difficile and Clostridium perfringens from foals. Equine Veterinary Journal, 45: 671-675. DOI: https://www.doi.org/10.1111/evj.12046

Sterne M, and Batty I (1975). Criteria for diagnosing Clostridial infection. Pathogenic clostridia, Butterworths, London, United Kingdom, pp. 79-122.

Thomas GM, and Joan AS (2009). Prevalence of net B among some clinical isolates of Clostridium perfringens from animals in the United States. Veterinary Microbiology, 136: 202-205. DOI: https://www.doi.org/10.1016/j.vetmic.2008.10.026

Titball RW, Naylor CE, Miller J, Moss DS, and Basak AK (2000). Opening of the active site of Clostridium perfringens $\alpha$-toxin may be triggered by membrane binding. International Journal of Medical Microbiology, 290: 357-361. DOI: https://www.doi.org/10.1016/S1438-4221(00)80040-5

Uzal FA, Freedman JC, Shrestha A, Theoret JR, Garcia J, Awad MM, Adams V, Moore RJ, Rood JI, and McClane BA (2014). Towards an understanding of the role of Clostridium perfringens toxins in human and animal diseases. Future Microbiol, 9(3): 361-377. DOI: https://www.doi.org/10.2217\%2Ffmb.13.168

Vaikosen ES, and Muller W (2001). Evaluating biochemical tests for isolation / identification of $C$. perfringens in faecal samples of small ruminants in Nigeria. Bulletin of Animal Health and Production in Africa, 49(4): 244-248.

Willis AT (1977). Anaerobic Bacteriology, Clinical and Laboratory Practice. 3rd Ed., Butter Worth, London, Boston, pp. 131-133. Available at: https://www.elsevier.com/books/anaerobic-bacteriology/willis/978-0-407-00081-0

Wilson GS, and Miles AA (1975). Principles of Bacteriology, Virology and Immunology. 6th Ed., vol. 1 and vol. 11, p. 1249 and p. 2706. Available at: https://www.cabdirect.org/cabdirect/abstract/19762704307

Yang W, Chou C, and Chinling W (2018). Characterization of toxin genes and quantitative analysis of netB in necrotic enteritis (NE)producing and non-NE-producing Clostridium perfringens isolated from chickens. Anaerobe, 54: 115-120. DOI: https://doi.org/10.1016/j.anaerobe.2018.08.010 
Yoo HS, Lee SU, Park KY, and Park YH (1997). Molecular Typing and Epidemiological Survey of Prevalence of Clostridium perfringens Types by Multiplex PCR. Journal of Clinical Microbiology, 35(1): 228-232. PMCID: 229544

Zhang J, Shui L, Lining X, Zhongmei W, Naiyu H, Tingting W, Xuming D, Jiakang H, and Wang J (2020). Verbascoside Protects Mice From Clostridial Gas Gangrene by Inhibiting the Activity of Alpha Toxin and Perfringolysin O. Frontiers in Microbiology, 11: 1504-1510. DOI: https://www.doi.org/10.3389/fmicb.2020.01504 